\title{
The Clinicopathological Findings of 121 Patients Presenting with Spontaneous Nipple Discharge
}

\section{Meme Başından Spontan Akıntı Șikayeti ile Başvuran 121 Olguya Ait Klinikopatolojik Bulgular}

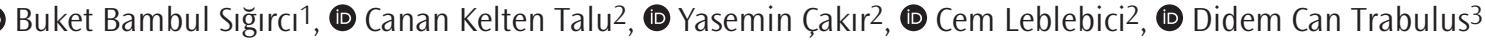 \\ ${ }^{1}$ Bahçelievler State Hospital, Clinic of Pathology, İstanbul, Turkey \\ 2University of Health Sciences Turkey, İstanbul Training and Research Hospital, Clinic of Clinical Pathology Laboratory, İstanbul, Turkey \\ 3University of Health Sciences Turkey, İstanbul Training and Research Hospital, Clinic of General Surgery, i̇stanbul, Turkey
}

\begin{abstract}
Introduction: This study aimed to investigate the cytopathological findings of patients who presented to our hospital with spontaneous nipple discharge. A cytological smear examination was performed to evaluate the correlation between cytology and biopsy in patients whose complementary biopsy or excision sampling was performed.

Methods: The nipple discharge smears of 121 patients sent to us over six years were retrospectively reviewed. Acellular smears without any cells were considered "insufficient", and smears that contained ductal cells, inflammatory cells, and foamy histiocytes were considered "sufficient". Smears considered sufficient for microscopic evaluation were classified and reported as "benign cytology", "compatible with papillary lesion", "suspicious for malignancy", and "malignant cytology".

Results: When the first smear samples of 121 patients were examined, "malignant cytology" was observed in one patient, "suspicious for malignancy" in two patients, "ductal ectasia" in one hundred and two patients, and "papillary lesion" in fourteen patients. The material was "acellular" in two patients. Nineteen patients were histopathologically diagnosed with malignancy $(n=7)$, ductal ectasia $(n=6)$, intraductal papilloma accompanied by florid-type intraductal hyperplasia without atypia $(n=2)$, intraductal papilloma $(n=2)$, complex sclerosing lesion $(n=1)$, and sclerosing papilloma $(n=1)$.
\end{abstract}

Conclusion: In cases where nipple discharge is persistent, repeated smear samples may contribute to the diagnosis if they contain epithelial components. In cases with histopathologically confirmed breast carcinoma, it should be kept in mind that the tumor may often show neuroendocrine features.

Keywords: Breast cancer, neuroendocrine features, ductal ectasia

\section{$\ddot{0} Z$}

Amaç: Bu çalıșmada, hastanemize spontan meme bașı akıntısı şikayeti ile başvuran ve akıntıdan yayma yapılan hastaların sitopatolojik bulgularını araștırmak ve tamamlayıcı biyopsi ve eksizyon spesmeni olan hastalarda sitoloji ve biyopsi korelasyonunun değerlendirilmesi amaçlanmıştır.

Yöntemler: Altı yıl süresince tarafımıza gönderilen, 121 hastaya ait meme başı akıntısı yaymaları retrospektif olarak incelendi. Hiç hücre içermeyen aselüler yaymalar "yetersiz", köpüksü histiosit, enflamatuvar hücre ve duktal hücrelerin izlendiği yaymalar "yeterli" olarak kabul edildi. Mikroskopik inceleme için yeterli kabul edilen yaymalar, "benign sitoloji”, "papiller lezyon ile uyumlu", "malignite şüphesi" ve "malign sitoloji” olarak sınıflandırıldı ve raporlandı.

Bulgular: Yüz yirmi bir hastaya ait ilk smear örnekleri incelendiğinde, hastalardan 1'inde "malign sitoloji", 2'sinde “malignite șüphesi”, 14'ünde "papiller lezyon” ve 102'sinde "duktal ektazi” saptandı. İki olguya ait materyal aselüler idi. Histopatolojik inceleme yapılabilen 19 olgudan 7'sinde malignite $(n=7)$, 6'sında duktal ektazi $(n=6), 2$ 'sinde atipisiz florid tip intraduktal hiperplazinin ( $n=2)$, eşlik ettiği intraduktal papillom ( $n=2)$, 2'sinde intraduktal papillom, 1'inde kompleks sklerozan lezyon $(n=1)$ ve 1'inde sklerozan papillom $(n=1)$ tespit edildi.

Sonuç: Kalıcı meme bașı akıntısı olan olgulara ait tekrarlanan yayma preparatlarında epitelyal içerik görülmesi tanıya katkıda bulunabilir. Histopatolojik olarak meme kanseri olduğu kesinleșmiş olgularda tümörde sıklıkla nöroendokrin değișikliklerin olabileceği akılda tutulmalıdır.

Anahtar Kelimeler: Meme kanseri, nöroendokrin özellikler, duktal ektazi

Cite this article as/Atıf: Bambul Sı ̆̆ırcı B, Kelten Talu C, Çakır Y, Leblebici C, Can Trabulus D. The Clinicopathological Findings of 121 Patients Presenting with Spontaneous Nipple Discharge. İstanbul Med J 2021; 22(2): 109-14.

(c) Copyright 2021 by the University of Health Sciences Turkey, Istanbul Training and Research Hospital/istanbul Medical Journal published by Galenos Publishing House.

(C) Telif Hakkı 2021 Să̆lık Bilimleri Üniversitesi istanbul Ĕgitim ve Araștırma Hastanesi/Istanbul Tıp Dergisi, Galenos Yayınevi tarafından basılmıștır. 


\section{Introduction}

Breast-related diseases are one of the most common health problems in women. Nipple discharge generally constitutes 3\%-5\% of breast-related symptoms in all women. However, $80 \%$ of women of reproductive age may encounter nipple discharge at least once in their lives $(1,2)$. The underlying causes of nipple discharge may be physiological or pathological. Most of the pathological causes develop due to benign lesions (intraductal papilloma, ductal ectasia, galactorrhea, trauma, use of some antipsychotics, and anti-hypertensive and antidepressant drugs) or at a lesser extent to malignant lesions (ductal/lobular/papillary breast carcinoma) $(3,4)$.

Nipple discharge may be clinically spontaneous/non-spontaneous or unilateral/bilateral or arise from a single duct or multiple ducts. The discharge can be bloody, milky, serous, or purulent. Among these, spontaneous, unilateral, bloody, and single-duct discharges particularly raise suspicion for malignancy (5-7). Breast ultrasonography (USG), mammography, and ductography are among the radiological examination methods that can be used for diagnostic purposes for patients presenting with nipple discharge. If an abnormality is detected on mammography or the lesion is palpable, fine needle aspiration biopsy (FNAB), tru-cut needle biopsy, or excisional biopsy is performed. However, in cases where there is no palpable lesion and no mammographic abnormality is detected, a direct smear from the discharge can be used to distinguish between malignant and benign lesions and for further diagnostic examination $(6,8,9)$.

In patients with nipple discharge, the diagnostic value of cytopathological examination depends on the amount and quality of the material. Some studies have reported that cytological examinations of nipple discharge are more useful in the diagnosis of malignant and "suspicious for malignancy" lesions rather than benign lesions (10).

In this study, we reviewed the cytopathological findings and clinicopathological features in patients who presented to our center with spontaneous nipple discharge and investigate the correlation of cytology/biopsy after excision/biopsy in patients with recurrent nipple discharge.

\section{Methods}

A total of 121 patients who applied to the İstanbul Training and Research Hospital, Clinic of Surgical within a period of six years between January 2011 and June 2017 and whose smears of nipple discharge were sent to the pathology laboratory were included in this study. This study was approved by the Ethical Committee of the University of Health Sciences Turkey, İstanbul Training and Research Hospital (approval number: 1220, date: 06.04.2018). Patients' consent was not obtained because the study was retrospective. The smear of each patient was retrieved from the archives of the pathology clinic and reevaluated. Of these 121 patients, 41 patients with continuing complaints who had recurrent admissions to our clinic and were sampled were identified. Two or more consecutive cytology-biopsy samples of these patients were reevaluated in combination. Information on the demographic characteristics, laterality of the lesion, and color/nature of the discharge was obtained through the intranet system of our hospital.
During the preparation of the smear, the material was obtained using the installation method in patients with spontaneous discharge after cleaning the nipple and applying gentle pressure to the breast with no discharge at that time. The collected samples were spread with the help of a second slide: Half of them were fixed in alcohol and stained by the Papanicolaou method, and the other half were air-dried and stained by May-Grünweld Giemsa method. FNAB materials were also prepared with the protocol applied to smears.

A pathologist specialized in breast pathology examined the smear preparations. Acellular smears, without any cells, are considered "insufficient" for microscopic examination. Smears with varying levels and contents of ductal epithelial cells, inflammatory cells, blood components, and foamy cells were considered "as sufficient" for microscopic examination. Smears that did not contain epithelial cells that could represent the lesion but contained inflammatory cells were also included in the adequate category. Accordingly, smears deemed sufficient for microscopic evaluation were classified as follows: (i) benign cytology (inflammatory nipple discharge, compatible with ductal ectasia), (ii) compatible with papillary lesion, (iii) suspicious for malignancy, and (iv) malignant cytology.

Synaptophysin and chromogranin immunostainings were performed on paraffin blocks containing the tumor tissue to reveal possible neuroendocrine differentiation (synaptophysin, rabbit monoclonal antibody MRQ-40, dilution: 1/250, Cell Marque Sigma-Aldrich Co., Rocklin, CA, and chromogranin A, mouse monoclonal antibody LK2H10, dilution: 1/250, Cell Marque Sigma-Aldrich Co., Rocklin, CA).

\section{Statistical Analysis}

Statistical analyses were performed using SPSS 22.0 for Windows (SPSS Inc., Chicago, IL, USA) package program. All data is presented as mean for parametric variables, and as percentage for categorical variables as descriptive statistics.

\section{Results}

One hundred and twenty patients were female (99.2\%), and one patient was male $(0.8 \%)$. The ages of the patients ranged between two and eighty-eight years (mean age: 47.4; median: 46). The youngest patient was a two-year old boy with a unilateral bloody nipple discharge. Smears of the nipple discharge from both breasts $(n=8 ; 6.6 \%)$, left breast $(n=52$; $43 \%)$, and right breast $(n=61 ; 50.4 \%)$ were prepared and examined. The nipple discharge was bloody in 104 (85.9\%) and serous in 17 (14.1\%) patients.

The first cytopathology samples of the cases were examined and reported as compatible with "malignant cytology" in one patient (0.8\%), "suspicious for malignancy" in two patients (1.6\%), "ductal ectasia" in 102 patients (84.3\%), and "papillary lesion" in 14 patients (11.6\%). The material of the two patients was "acellular" (1.6\%) (Figure 1).

Eighty of 121 patients who presented with the complaint of spontaneous nipple discharge were sampled only once, while 41 patients underwent two or more cytology or biopsy samplings. In 19 of these 41 patients (15.7\%), the final diagnosis was made by performing a biopsy or surgical excision. Accordingly, nipple discharge smears of seven patients (36.8\%) 
were marked as "malignancy"; smears of six patients (31.6\%), "ductal ectasia"; smears of two patients (10.5\%), "intraductal papilloma" accompanied by florid-type intraductal hyperplasia without atypia;

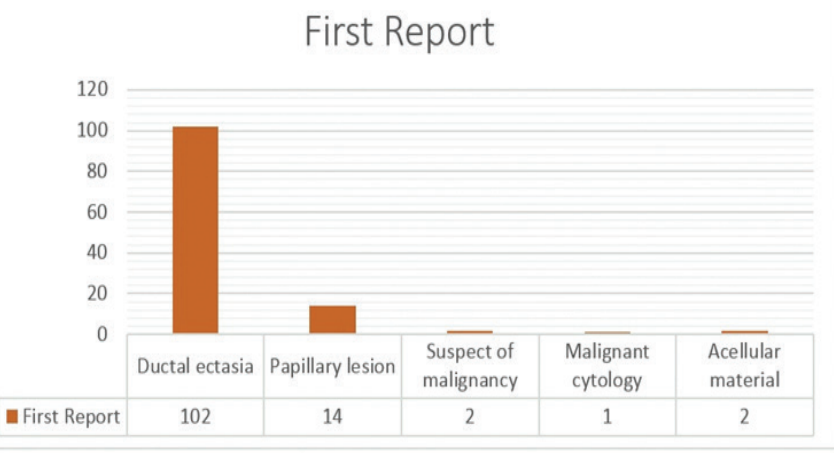

Figure 1. Initial pathology reports of 121 patients with nipple discharge smears of two patients (10.5\%), "intraductal papilloma"; smears of one patient (5.3\%), "complex sclerosing lesion"; smears of one patient (5.3\%), "sclerosing papilloma" (Table 1).

On the first sampling, the nipple discharge smears of seven patients were marked as "malignancy"; smears of four patients, "ductal ectasia"; smears of two patients, "papillary lesion/neoplasia"; smears of one patient "malignant cytology" (Table 2) When the first radiological images (USG/mammography) of all seven patients, whose smears were marked as "malignancy" in the pathology report, were examined, it was found that two of the seven patients were reported as Birads-3 (probably benign), one patient as Birads-4 (suspicious), and four patients as Birads-5 (highly suggestive of malignancy). The nipple discharge originated from the right breast in four patients and from the left breast in three of these seven cases. In six patients, the discharge was bloody, and in one patient, it was serous. The age of the patients diagnosed with malignancy ranged from 30 to 71 years, with a mean age of 52.8 years.

Table 1. Patients with histopathological biopsy or excision materials $(n=19)$

\begin{tabular}{|l|l|l|}
\hline & (n) & (\%) \\
\hline Malignancy & 7 & $36.8 \%$ \\
\hline Ductal ectasia & 6 & $31.6 \%$ \\
\hline "Intraductal papilloma" accompanied by florid-type intraductal hyperplasia without atypia & 2 & $10.5 \%$ \\
\hline Intraductal papilloma & 2 & $10.5 \%$ \\
\hline Complex sclerosing lesion & 1 & $5.3 \%$ \\
\hline Sclerosing papilloma & 1 & $5.3 \%$ \\
\hline & 19 & $\mathbf{1 0 0} \%$ \\
\hline
\end{tabular}

\section{Table 2. Analysis of patients whose tissue biopsy/excision is reported as "malignant"}

\begin{tabular}{|c|c|c|c|}
\hline Patient & Accurate diagnosis & Age and symptoms & Pathology report \\
\hline 1 & Invasive tubular carcinoma & $\begin{array}{l}30 \text { years old; } \\
\text { Unilateral, non-bloody discharge }\end{array}$ & $\begin{array}{l}\text { 1. Right nipple smear: compatible with intraductal papilloma (2012), } \\
\text { 2. Right breast tru-cut biopsy: intraductal proliferative lesion (2012), } \\
\text { 3. Right breast quadrantectomy: invasive tubular carcinoma, NG: } 2 \text { (2012). }\end{array}$ \\
\hline 2 & Invasive ductal carcinoma & $\begin{array}{l}71 \text { years old; } \\
\text { Unilateral, bloody discharge }\end{array}$ & $\begin{array}{l}\text { 1. Right nipple smear: compatible with ductal ectasia (2012), } \\
\text { 2. Right breast BCS: invasive ductalcarcinoma, NG: } 2 \text { (2012). }\end{array}$ \\
\hline 3 & $\begin{array}{l}\text { Invasive ductal carcinoma } \\
\text { with marked DCIS } \\
\text { component }\end{array}$ & $\begin{array}{l}45 \text { years old; } \\
\text { Unilateral, bloody discharge }\end{array}$ & $\begin{array}{l}\text { 1. Left nipple smear: papillary neoplasia (2013), } \\
\text { 2. Left breast tru-cut biopsy: DCIS, NG: } 2 \text { (2013), } \\
\text { 3. Left breast MRM: invasive ductal carcinoma with marked DCIS } \\
\text { component (2013). }\end{array}$ \\
\hline 4 & Invasive ductal carcinoma & $\begin{array}{l}54 \text { years old; } \\
\text { Unilateral, bloody discharge }\end{array}$ & $\begin{array}{l}\text { 1. Left nipple smear: malignant cytology (2015), } \\
\text { 2. Left breast tru-cut biopsy: invasive ductal carcinoma, NG: } 3 \text { (2015), } \\
\text { 3. Left breast MRM: invasive ductal carcinoma, NG: } 3 \text { (2015). }\end{array}$ \\
\hline 5 & Invasive breast carcinoma & $\begin{array}{l}39 \text { years old; } \\
\text { Unilateral, bloody discharge }\end{array}$ & $\begin{array}{l}\text { 1. Right nipple smear: compatible with ductal ectasia (2015), } \\
\text { 2. Right breast tru-cut biopsy: invasive breast carcinoma, NG: } 2 \text { (2015). }\end{array}$ \\
\hline 6 & Invasive ductal carcinoma & $\begin{array}{l}64 \text { years old; } \\
\text { Unilateral, bloody discharge }\end{array}$ & $\begin{array}{l}\text { 1. Left nipple smear: compatible with ductal ectasia (2017), } \\
\text { 2. Left beast tru-cut biopsy: invasive ductal carcinoma, NG:2 (2017), } \\
\text { 3. Left breast BCS: invasive ductal carcinoma, NG: } 2 \text { (2017). }\end{array}$ \\
\hline 7 & $\begin{array}{l}\text { DCIS papillary/solid/ } \\
\text { neuroendocrine pattern }\end{array}$ & $\begin{array}{l}67 \text { years old; } \\
\text { Unilateral, bloody discharge }\end{array}$ & $\begin{array}{l}\text { 1.Right nipple smear: compatible with ductal ectasia (2015), } \\
\text { 2.Right breast FNAB: suspicious for malignancy (2015), } \\
\text { 3. Right breast excisional biopsy: DCIS papillary/solid/neuroendocrine } \\
\text { pattern, NG: } 2 \text { (2015). }\end{array}$ \\
\hline
\end{tabular}


Synaptophysin and chromogranin immunostainings were performed on paraffin blocks containing the tumor tissue of two patients, except for the patient with ductal carcinoma in situ (DCIS). In one of these patients, cytoplasmic immunostaining for both markers was identified in more than $90 \%$ of tumor cells, while neuroendocrine markers were negative in another patient. Estrogen receptor, progesterone receptor, human epidermal growth factor receptor-2, Ki-67, chromogranin, and synaptophysin status of the seven patients diagnosed with malignancy are shown in Table 3.

While the first nipple discharge of a 50-year-old female patient, who presented with the complaint of bloody discharge from the right nipple, was reported as "compatible with ductal ectasia," the FNAB sample made upon the continuation of her complaint was reported as "malignant cytology." The definitive diagnosis could not be achieved as the patient did not undergo biopsy/excision in our hospital.

Seven of eight patients with bilateral nipple discharge also had a bloody nipple discharge. Direct smear samples from the nipple discharge of these patients were reported as "compatible with ductal ectasia," and repeated hospital admissions with the same complaint were not detected.

\section{Discussion}

Niple discharge is the one of the challenging situation in breast lesions. Although nipple discharge is frequently associated with an underlying benign disease, it is related to malignancy in 1.2\%-15\% of patients (11). For this reason, accurate, fast, and non-invasive diagnostic methods are needed. Although direct cytological examination of the smear prepared from the nipple discharge is a non-invasive and easily applicable method, its place in routine practice is unfortunately limited. Many studies have indicated that the cytological method in nipple discharge samples has low sensitivity but higher specificity rates and an inadequate diagnostic value (12-15).

In studies conducted in the literature on the nipple discharge, varying specificity and sensitivity rates have been reported. These specificity and sensitivity rates were, respectively, $66.1 \%$ and $16.7 \%$ in the study by Kooistra et al. (12) ( $n=618), 100 \%$ and $55.6 \%$ in the study by Lee (14) $(n=174)$, and $97.4 \%$ and $31.2 \%$ in the study by Dinkell et al. (16) ( $n=384)$. In the study by Castellano et al. (17) on 139 patients, the specificity, sensitivity, and positive and negative predictive values were found to be $100 \%, 58 \%, 100 \%$, and $63 \%$, respectively, and a significant relationship was reported between the cytological examination of malignant nipple discharge and lesion size.

To clarify the debates made for the importance of cytological examination of nipple discharge for diagnosis, Li et al. (18) conducted a meta-analysis study on 12 articles (1,476 patients), which met the inclusion criteria, of 286 articles. Accordingly, the sensitivity and specificity of nipple discharge cytology in predicting breast cancer were $63 \%$ and $95 \%$, respectively. According to this meta-analysis, it was stated that the cytological examination of the samples prepared from the nipple discharges was a useful method that had a moderate sensitivity and high specificity in predicting breast malignancies in patients with a pathological nipple discharge (18).

In our study, the specificity, sensitivity, and positive and negative predictive values of the cytological examination of nipple discharge were $97.1 \%, 14.3 \%, 50 \%$, and $65 \%$. In this study, most of the initial smears did not contain epithelial components that could represent the lesion, and additional samples could not be obtained for all patients. Therefore, the sensitivity rate was low. However, more accurate results were obtained in cases where the cytological samplings were repeated or tissue biopsy samples were taken due to the complaint of ongoing discharge. In our series, the first diagnosis of cytological materials of four of seven patients, whose histological diagnosis was malignant, was reported as "compatible with ductal ectasia," and there were no epithelial cells or groups of cells in their samples of smears. The first cytological samples of the other two malignant cases suggested the presence of a papillary lesion. Whereas the subsequent tru-cut biopsy specimen of one of these patients was compatible with DCIS, the specimen of another patient was compatible with an intraductal proliferative lesion. However, in the latter patient, a small focus of invasive tubular carcinoma was detected in the ipsilateral breast, simultaneously (patient 1 in Table 2). Another patient whose first cytological diagnosis was reported as "ductal ectasia" and whose nipple discharge sampling was repeated due to the persistence of her complaints was found to be suspicious for malignancy because of the presence of a small amount of monotonous epithelial population with cytonuclear atypia. This patient was diagnosed with DCIS (pattern: papillary, solid, neuroendocrine type, nuclear grade 2) in the subsequent examination of the excision material (patient 7 in Table 2). Patient 7 is the only patient diagnosed with DCIS in our series, and it is interesting as it shows diffuse cytoplasmic staining with synaptophysin, a neuroendocrine marker (patient 7 in Table 3). In a study of 89 patients, who presented with symptomatic nipple

Table 3. ER, PR HER2, Ki-67, synaptophysin, and choromogranin status of patients diagnosed with malignancy

\begin{tabular}{|c|c|c|c|c|c|c|}
\hline & ER & PR & HER-2 & Ki-67 & Synaptophysin & Chromogranin \\
\hline Patient 1 & $80 \%, \mathrm{MP}$ & $90 \%, \mathrm{SP}$ & Score 0 (negative) & $15 \%$ & NP & NP \\
\hline Patient 2 & $30 \%-40 \%$, L-MP & $40 \%-50 \%$, MP & Score 0 (negative) & $10 \%$ & NP & NP \\
\hline Patient 3 & 7\%, L-MP & Negative & Score 3 (positive) & $30 \%-35 \%$ & NP & NP \\
\hline Patient 4 & Negative & Negative & Score 0 (negative) & $50 \%$ & NP & NP \\
\hline Patient 5 & $80 \%, \mathrm{SP}$ & $90 \%, \mathrm{SP}$ & Score 0 (negative) & $10 \%$ & Diffuse positive & Diffuse positive \\
\hline Patient 6 & $100 \%, \mathrm{SP}$ & $98 \%, \mathrm{SP}$ & Score 0 (negative) & $15 \%$ & Negative & Negative \\
\hline Patient 7 & Diffuse nuclear positive & Diffuse nuclear positive & NP & NP & Diffuse cytoplasmic positive & Negative \\
\hline
\end{tabular}

ER: Estrogen receptor, PR: progesterone receptor, HER-2: human epidermal growth factor receptor-2, MP: medium positive, L-MP: low-medium positive, SP: strong positive, NP: not performed 
discharge and in which samples were examined histologically, breast carcinoma was observed in 55 patients (61.8\%). Of these 55 patients, 24 patients (43.6\%) showed expression with neuroendocrine markers (synaptophysin or chromogranin) in more than $50 \%$ of tumor cells and were diagnosed with neuroendocrine breast tumor. While the samples of nine of these 24 patients showed foci of DCIS, the samples of the rest of the patients showed both invasive and in situ components. Interestingly, immunohistochemical staining at varying levels with neuroendocrine markers was detected in all patients with breast carcinoma (31 patients), except these 24 patients, and it was mentioned that neuroendocrine features were detected at a high rate in patients with breast carcinoma presenting with nipple discharge (19). In our series, apart from the patient with DCIS, two more patients who have paraffin blocks containing the tumor tissue were determined, and synaptophysin and chromogranin immunostainings were used to reveal possible neuroendocrine differentiation (patients 5 and 6, Table 3). In one of these patients, invasive breast carcinoma with neuroendocrine features was detected, which showed cytoplasmic immunostaining for both markers in more than $90 \%$ of tumor cells (patient 5). In our series, it is remarkable that two of three patients, where immunostaining was applied, had breast tumors with neuroendocrine features. In this respect, immunohistochemical staining and investigation of neuroendocrine features in patients presenting with nipple discharge and diagnosed with breast cancer may provide important data. Neuroendocrine tumors of the breast are uncommon, and their relationship with a bloody nipple discharge is important and new information $(19,20)$. They were first defined as a separate entity in the World Health Organization breast booklet in 2003 and have been increasingly described in the last two decades $(20,21)$.

The clinical features of nipple discharge can also aid in the diagnosis. In many studies, where the patient's age was $\geq 50$, the fact that nipple discharge is unilateral, spontaneous, and bloody was defined as a probable sign of malignancy (5,22). In a study by Kan et al. (23) on 102 patients, it was reported that if the nipple discharge was not bloody, the underlying pathology was often benign, and negative radiological imaging methods supported their findings. In our study, bloody nipple discharge was observed in six of seven patients diagnosed with malignancy, and all patients had a unilateral nipple discharge. Additionally, on radiological examination, five of seven patients were reported as "suspicious" or "highly suggestive of malignancy." These findings support the previous study's results. Although the mean age of the patients in this study was 52.4 years, four patients were 50 years and older, and three patients were under 50 years of age.

\section{Study Limitations}

The limitations of our study are as follows: the retrospective character of our study, the absence of biopsy or excision specimens of all patients, and the inability to perform histopathological examination.

\section{Conclusion}

Smears of patients who presented to the clinic with nipple discharge may have low sensitivity and medium-high specificity in the identification of lesions. Smears in which cytological examination suggests "ductal ectasia" (presence of histiocyte based on proteinaceous material) and with no epithelial component representing the lesion may indicate an underlying malignancy in patients with persistent nipple discharge. In such cases, resampling of nipple discharge as a smear or tissue biopsy of the lesion may increase the chance of detecting malignancy. It should also be kept in mind that breast tumors with neuroendocrine features may be seen in patients presenting with nipple discharge.

Ethics Committee Approval: This study was approved by the Ethical Committee of the University of Health Sciences Turkey, İstanbul Training and Research Hospital (approval number: 1220, date: 06.04.2018).

Informed Consent: Patients' consent was not obtained because the study was retrospective.

Peer-review: Externally peer-reviewed.

Authorship Contributions: Surgical and Medical Practices - D.C.T.; Concept - B.B.S.; Design - B.B.S., C.K.T.; Data Collection or Processing B.B.S., Y.C..; Analysis or Interpretation - C.K.T., Y.C.., C.L.; Literature Search - Y.Ç., C.L.; Writing - B.B.S.

Conflict of Interest: No conflict of interest was declared by the authors.

Financial Disclosure: The authors declared that this study received no financial support.

\section{References}

1. Bland $\mathrm{KI}, \mathrm{C} . \mathrm{E}$. , Goodson WH, King EB, The Breast: Comprehensive management of Benign and Malignant disorders. 3 ed. WB Saunders: 2005. p. 65-90

2. Fung A, Rayter Z, Fisher C, King DM, Trott P. Preoperative cytology and mammography in patients with single-duct nipple discharge treated by surgery. Br J Surg 1990; 77: 1211-2.

3. Louie LD, Crowe JP, Dawson AE, Lee KB, Baynes DL, Dowdy T, et al Identification of breast cancer in patients with pathologic nipple discharge: does ductoscopy predict malignancy? Am J Surg 2006; 192: 530-3.

4. Van Zee KJ, Ortega Pérez G, Minnard E, Cohen MA. Preoperative galactography increases the diagnostic yield of major duct excision for nipple discharge. Cancer 1998; 82: 1874-80.

5. latrakis G. Benign diseases of the breast. Iatrakis G, editor. Book of Gynecology. a. Desmos Publications, Athens: Greece; 2006. p. 707-14.

6. El-Daly H, Gudi M. Evaluation of nipple discharge cytology and diagnostic value of red blood cells in cases with negative cytology: a cytohistologic correlation. Acta Cytol 2010; 54: 560-2.

7. Ciatto S, Bravetti P, Cariaggi P. Significance of nipple discharge clinical patterns in the selection of cases for cytologic examination. Acta Cytol 1986; 30: 17-20.

8. Gioffrè Florio M, Manganaro T, Pollicino A, Scarfo P, Micali B. Surgical approach to nipple discharge: a ten-year experience. J Surg Oncol 1999; 71: 235-8.

9. Jayaram G, Elsayed EM, Yaccob RB. Papillary breast lesions diagnosed on cytology. Profile of 65 cases. Acta Cytol 2007; 51: 3-8.

10. Hou M, Tsai K, Lin H, Chai C, Liu C, Huang T. A simple intraductal aspiration method for cytodiagnosis in nipple discharge. Acta Cytol 2000; 44: 1029-34.

11. Salmon R], Merle S, Boue P. [Demonstration of blood in nipple discharges using the Hemoccult]. J Gynecol Obstet Biol Reprod 1987; 16: 595-8.

12. Kooistra BW, Wauters C, van de Ven S, Strobbe L. The diagnostic value of nipple discharge cytology in 618 consecutive patients. Eur J Surg Oncol 2009; 35: 573-7. 
13. Gray RJ, Pockaj BA, Karstaedt PJ. Navigating murky waters: a modern treatment algorithm for nipple discharge. Am J Surg 2007; 194: 850-5.

14. Lee WY. Cytology of abnormal nipple discharge: a cyto-histological correlation. Cytopathology. 2003; 14: 19-26.

15. Pritt B, Pang Y, Kellogg M, St John T, Elhosseiny A. Diagnostic value of nipple cytology: study of 466 cases. Cancer 2004; 102: 233-8.

16. Dinkel HP, Gassel AM, Müller T, Lourens S, Rominger M, Tschammler A. Galactography and exfoliative cytology in women with abnormal nipple discharge. Obstet Gynecol 2001; 97: 625-9.

17. Castellano I, Metovic J, Balmativola D, Annaratone L, Rangel N, Vissio E, et al. The impact of malignant nipple discharge cytology (NDC) in surgical management of breast cancer patients. PLoS One 2017; 12: e0182073.

18. Li XQ, Xu F, Lei CQ, Li J, Jiang HC. Accuracy for cytological evaluation in the detection of breast cancer among patients with pathologic nipple discharge: a PRISMA-compliant meta-analysis. Chin Med J (Engl) 2020; 133: 435-43.
19. Kawasaki T, Mochizuki K, Yamauchi $\mathrm{H}$, Yagata $\mathrm{H}$, Kondo $\mathrm{T}$, Tsunoda $\mathrm{H}$, et al. High prevalence of neuroendocrine carcinoma in breast lesions detected by the clinical symptom of bloody nipple discharge. Breast 2012; 21: 652-6.

20. Kelten Talu C, Leblebici C, Kilicaslan Ozturk T, Hacihasanoglu E, Baykal Koca S, Gucin Z. Primary breast carcinomas with neuroendocrine features: Clinicopathological features and analysis of tumor growth patterns in 36 cases. Ann Diagn Pathol 2018; 34: 122-30.

21. Kelten Talu C, Savli TC, Huq GE, Leblebici C. Histopathological and Clinical Differences Between Primary Breast Carcinomas With Neuroendocrine Features and Primary Breast Carcinomas Mimicking Neuroendocrine Features. Int J Surg Pathol 2019; 27: 744-52.

22. Leis HP Jr. Management of nipple discharge. World J Surg 1989; 13: 736-42.

23. Kan WM, Chen C, Kwong A. Implications of nipple discharge in Hong Kong Chinese women. Hong Kong Med J 2018; 24: 18-24. 